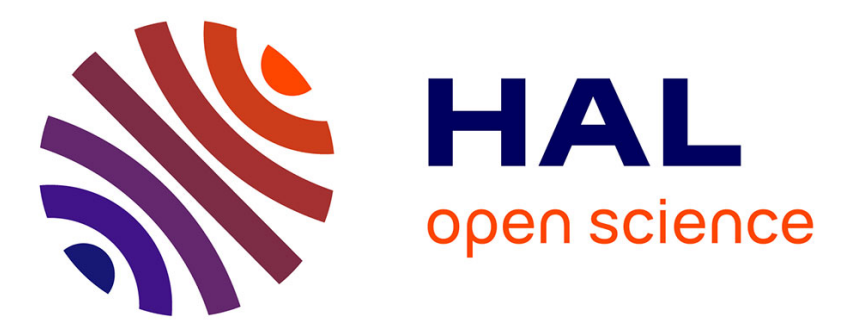

\title{
Accelerated weathering of cementitious matrix for the development of an accelerated laboratory test of biodeterioration
}

Virginie Wiktor, Philippe Grosseau, René Guyonnet, Eric Garcia-Diaz, Christine Lors

\section{To cite this version:}

Virginie Wiktor, Philippe Grosseau, René Guyonnet, Eric Garcia-Diaz, Christine Lors. Accelerated weathering of cementitious matrix for the development of an accelerated laboratory test of biodeterioration. Materials and structures, 2010, pp.doi: 10.1617/s11527-010-9653-1. 10.1617/s11527-0109653-1 . hal-00542958

\section{HAL Id: hal-00542958 https://hal.science/hal-00542958}

Submitted on 4 Dec 2010

HAL is a multi-disciplinary open access archive for the deposit and dissemination of scientific research documents, whether they are published or not. The documents may come from teaching and research institutions in France or abroad, or from public or private research centers.
L'archive ouverte pluridisciplinaire HAL, est destinée au dépôt et à la diffusion de documents scientifiques de niveau recherche, publiés ou non, émanant des établissements d'enseignement et de recherche français ou étrangers, des laboratoires publics ou privés. 


\title{
Accelerated weathering of cementitious matrix for the development of an accelerated laboratory test of biodeterioration
}

\section{Virginie WiKtor (1,2), PhilipPe Grosseau (1)*, RENE GUYONNET(1), ERIC GARCIA- DIAZ(2), CHRISTINE LORS(2)}

(1) Ecole Nationale Supérieure des Mines de Saint Etienne ; Centre SPIN ; Département PMMC ; LPMG-UMR CNRS 5148 ; 158 Cours Fauriel, 42023 Saint-Étienne Cedex 2, France

(2) Ecole des Mines de Douai, Département Génie-Civil et Environnemental, 941 rue Charles Bourseul, BP 838, 59508 Douai Cedex, France

\begin{abstract}
Cement based materials are porous, may contain organic adjuvants, and thus possesses an important primary bioreceptivity. To preserve constructions from fungal colonization and to act efficiently against fungal biodeterioration, it is necessary to have a better understanding of biodeterioration mechanisms and its effects on materials properties. An accelerated laboratory test which allows us to compare the growth of three fungal strains and the aesthetic biodeterioration of a cementitious matrix was developed. As the surface $\mathrm{pH}$ of the fresh cement specimen is too high to allow fungal growth $(\mathrm{pH} \sim 12)$, accelerating weathering of the matrix, consisting of the combination of carbonation and leaching, was performed to reduce the matrix alkalinity. XRD analyses and SEM observations pointed out that the matrix surface is progressively covered by a calcium carbonate layer as the weathering increases. Results point out that the microbial growth occurs on matrix with a surface composition more like a limestone than a cementitious one.
\end{abstract}

Keywords:

Biodeterioration ; Cement paste ; Carbonation ; Leaching ; Accelerated weathering ; Microbial growth

\section{Introduction}

Micro-organisms-bacteria, cyanobacteria, fungi, algae, and lichens-are liable to grow on building materials. Biological activity contributes to deterioration of building material, and its interaction with physico-chemical mechanisms is considered central to understanding the long term deterioration [47]. Physical, chemical, and biological agents act in co-association, ranging from synergistic to antagonistic, to deteriorate stone [63].

In Civil Engineering the most widely used material is concrete for different kind of application: bridge construction, sewer pipes, buildings and in some case during restoration of Cultural Heritage Monuments. Cement plays an essential role in concrete works behaviour, because it provides its mechanical resistance [32]. Cement based materials are porous, may contain organic adjuvants, and thus possess an important primary bioreceptivity.

Bioreceptivity, as defined by Guillitte [31], is the totality of materials properties that contribute to the establishment, anchorage and development of fauna and/or flora. Primary bioreceptivity is the initial potential of colonisation [31].

* Corresponding author: grosseau@emse.fr 
Fungi are among the most harmful organisms associated to biodeterioration of organic and inorganic materials [58]. Their occurrence on the stones is reported to be combined not only with aesthetic spoiling of the monuments, due to colour changes and black spots, but also there is strong evidence that these organisms can colonize deeper cracks, cause crater shaped lesions, chipping and exfoliation of the rock surface combined with the loss of materials [58, $65]$.

In general, two main groups of fungi are usually isolated from rock surfaces [8]: (i) one group includes species of the genera of Hyphomycetes and Coelomycetes among which are included those that do not produce melanin, like Fusarium, Penicillium, Aspergillus, Phoma and those that are black pigmented like Alternaria, Ulocladium, Cladosporium melanin producers. They are fast growing fungi. (ii) The second group includes the so-called black yeasts and meristematic fungi. They are a wide and heterogeneous group of black pigmented fungi that share common characteristics such as the presence of melanins within the cells (swollen cells), hyphae and/or spores. The production of melanin and the meristematic development allow them to survive in stressed environmental conditions like low humidity and high sun irradiation [6]. For this group of fungi is also used the term of rock-inhabiting fungi to underline the exclusive isolation of many of them from rock surface [8]. The black fungi have the capacity to: (i) settle on the rocks surface, (ii) attach firmly to the surface and (iii) penetrate deeper into the rock. The major aesthetic damage, however, may occur when environmental conditions do not force fungi into the crevices, but due to favourable conditions for fungal growth they spread over the rock surface [14].

To preserve constructions from fungal colonisation and to act efficiently against fungal biodeterioration, it is necessary to have a better understanding of biodeterioration mechanisms and its effects on materials properties. Synthetic stone such as concrete, brickwork and mortar show microbial colonisation once their initial highly alkaline $\mathrm{pH}(>12)$ falls after a period of weathering $(<10)$ [1]. At the moment, tests to study biodeterioration of building materials exist. Some of them were developed without accelerated weathering of the matrix and so lead to experiment time ranging from 7 to 15 months $[46,56]$. On the other hand, accelerated weathering of the matrix may reduce the duration of the experiment by increasing matrix bioreceptivity. Whereas accelerated weathering of the matrix to enhance its bioreceptivity is not truly innovative in biodeterioration study [3,10, 11, 18, 19, 45, 49], only very few studies $[10,49]$ focus on the accelerated test for fungal biodeterioration.

An accelerated laboratory test which allows us to compare the growth of three fungal strains and the biodeterioration involved on a cementitious matrix was developed. We paid particular attention to accelerate the matrix weathering so as to not exceed 3 months of experiment. Three fungal strains were selected for the test in order to represent main kind of fungi involved in biodeterioration in natural environment [7, 24, 51, 55, 57, 63, 65]: Alternaria alternata to represent a melanin producer Hyphomycete, Exophiala sp. for yeast like fungi, and Coniosporium uncinatum (MC 557) as meristematic fungi. Aesthetical and physical biodeterioration was expected from the development of Alternaria alternata, Exophiala sp., Coniosporium uncinatum with hyphae penetration inside the matrix.

The aim of this paper is to present the accelerated weathering operation which promotes fungal development on hardened cement paste: carbonation and leaching operations are performed to reduce matrix surface $\mathrm{pH}$. The specimens (weathered and non-weathered) are first physico-chemically characterized, and then influence of the matrix weathering on the fungal development is studied.

\section{Background}

Once the cement based material has been made, leaching and ageing, and more specifically carbonation, start changing the original characteristics of the material. In nature, carbonation and leaching occur intermittently and alternately during the life cycle of the material [62]. 


\section{II.1. Carbonation}

Carbonation is considered the most common chemical reaction influencing the performance of cement based materials in natural environment scenarios [38].

The penetration of gaseous carbon dioxide within partially saturated concrete usually initiates a series of reactions with both ions dissolved in the pore solutions and the hydrated cement paste. The whole process can be summarized as a series of different steps [27, 29, 54]: Gaseous carbon dioxide first penetrates the material. It then dissolves in pore solution mainly as $\mathrm{HCO}_{3}{ }^{-}$and $\mathrm{CO}_{3}{ }^{2-}$. The $\mathrm{CO}_{3}{ }^{2-}$ species then reacts with dissolved calcium to precipitate calcite, $\mathrm{CaCO}_{3}$, as well as other $\mathrm{CO}_{2}$-based solid phases. The $\mathrm{pH}$ drop associated with reactions leads to the dissolution of portlandite. Because carbonation products have higher molar volumes than the parent hydrates $\mathrm{Ca}(\mathrm{OH})_{2}$ and $\mathrm{C}-\mathrm{S}-\mathrm{H}$, a decrease of porosity is expected [27, 60].

Progressive carbonation eventually leads to depletion of portlandite and subsequently decalcification of $\mathrm{C}-\mathrm{S}-\mathrm{H}$ to provide new portlandite for the carbonation reaction [27]. This decomposition of $\mathrm{C}-\mathrm{S}-\mathrm{H}$ is reported to increase [27] or decrease [44] porosity.

Since carbonation process in natural environments may be very slow, laboratory experimentation has been conducted under a variety of carbon dioxide levels. Many of the studies used low levels of $\mathrm{CO}_{2}$ (i.e. $4-5 \% \mathrm{CO}_{2}$ ) $[2,13]$. Accelerated carbonation studies using $100 \% \mathrm{CO} 2$ [2, 21, 36, 37, 59]; allow the characterization of carbonation processes in much shorter times.

\section{II.2. Leaching}

The leaching of ions (mainly calcium and hydroxide) from the pore solution to the external environment is responsible for the dissolution of portlandite and $\mathrm{C}-\mathrm{S}-\mathrm{H}$ [29]. The leaching of calcium is a coupled dissolution/diffusion process. Leaching by deionized water induces calcium and hydroxide concentration gradients which continuously decrease from the sound zone to the exposed surface of the material. This causes the diffusion of calcium and hydroxide ions from the pore solution to the aggressive solution, and thus lowers the amount of calcium concentration in the pore solution [29]. Loss of calcium leads to the dissolution of portlandite and secondary precipitations of AFm, ettringite and calcite [22, 23, 29].

The degraded zone induced by water exposure is characterized by a decalcification of $\mathrm{C}-\mathrm{S}-\mathrm{H}$ inducing a silicate polymerization. The $\mathrm{Ca} / \mathrm{Si}$ ratio of the $\mathrm{C}-\mathrm{S}-\mathrm{H}$ gradually decreases between sound and leached zone $[29,34,39]$.

Other factors affecting the rate and amount of leaching include the type and amount of constituent investigated, the alkalinity of the matrix, and the chemical properties of the pore water and leachant ( $\mathrm{pH}$, ionic strength, etc,...) [62].

Alteration of the chemical behaviour of the matrix resulting from carbonation influences the release of species from the matrix during leaching [25]. Carbonation and leaching are widely investigated together in studies for the use of hazardous wastes in cementitious matrix. Many studies have investigated the effect of carbonation on the leaching of heavy metals [25, 37, 48, $59,61,62]$. In these studies, the carbonation is mainly performed during the cement hydration. Few focuses on the leaching of carbonated specimens after the curing period, from microstructural point of view. With respect to the effect on pore size distribution, both leaching and carbonation decrease the amount of smaller pores [62].

The research presented here was carried out to evaluate the changes undergone by the cementitious matrix as a result of accelerated weathering. The specific objectives were (i) to characterize the cementitious matrix after each weathering step (carbonation and leaching), and (ii) to evaluate the influence of the matrix accelerated weathering on the fungal growth. The microstructure of the cementitious matrix is investigated by X-ray diffraction (DRX), Fourier Transform Infrared spectroscopy (FT-IR), Scanning Electron Microscopy with X-ray microanalyses (SEM/EDS). 


\section{Materials and methods}

\section{III.1. Matrix preparation}

The study was conducted with ordinary white Portland cement CEM I 52.5 R. The Water/Cement ratio determines the capillary porosity of the cement paste: the higher this ratio, the higher the capillary porosity, but also the higher is the bleeding effect. A higher porosity favours microbial development [31]. The best compromise between bleeding effect and capillary porosity is obtained in our case with a W/C mass ratio of 0.55. Hardened cement paste samples are prisms, $1 \times 2.5 \times 8.5 \mathrm{~cm}$. Samples were demolded $24 \mathrm{~h}$ after production and stored 28 days at $100 \%$ relative humidity, at room temperature. Accelerated weathering is performed with carbonation for $48 \mathrm{~h}$, or carbonation ( $48 \mathrm{~h}$ ) and leaching operation (28 days) as described by Wiktor et al. [64]. Briefly, specimens are exposed to pure $\mathrm{CO}_{2}$ flow under controlled relative humidity ( $65 \%$ HR) for carbonation. Then, the carbonated specimens are dived into deionized water which is totally renewed in $24 \mathrm{~h}$. Specimens were exposed overnight to UV light for sterilization.

\section{III.2. Analyses}

\section{III.2.1. $X$-ray diffraction (DRX)}

The XRD analyses were carried out using $\mathrm{Cu} \mathrm{K}_{a}$ radiation $(\lambda=1.5406 \AA)$ on Brukner D8 advance device. The XRD scans were recorded from 5 to $59^{\circ} 2 \theta$ with 0.040 step width and $5 \mathrm{~s}$ counting time. The analyses were directly performed on the bulk specimen; hence about the first hundred micrometers were analyzed.

\section{III.2.2. Fourier transform infrared spectroscopy (FT-IR)}

FT-IR analyses were carried out with Biorad FTS 185 (digilab) equipment using Attenuated Total Reflexion (ATR) unit. The spectra were usually recorded in the range of 4,000$400 \mathrm{~cm}^{-1}$ with $2 \mathrm{~cm}^{-1}$ resolution, and 32 scans were collected each time. The ATR analyses require very small amount of sample $(\sim 1 \mathrm{mg})$, and furthermore no preparation or dilution of the sample is needed. The surface of our specimens was gently scraped and analysed. Hence FT-IR analyses provided information from the first $500 \mu \mathrm{m}$.

\section{III.2.3. Scanning electron microscope equipped with $X$-ray microanalyses (SEM/EDX)}

The fractured surface samples were obtained from the specimens non-weathered, carbonated then leached, and carbonated only. Specimens' cross-sections were also prepared. They were vacuum impregnated with epoxy resin, and polished sections were prepared in the Civil engineering department of Ecole des Mines de Douai.

For the investigation by SEM and EDX, the samples were dried in a desiccator for $24 \mathrm{~h}$, and subsequently gold/palladium coated. Observations were carried out with a JEOL 840 SEM/EDX. Figure 1 shows the different areas analyzed for the EDX analyses.

Each analysis is performed on a surface about $20 \times 200 \mu \mathrm{m}$. Calcium, silicon, and aluminium are assayed.

\section{III.3. Microbiological techniques}

\section{III.3.1. Fungal strains and cultural media}

Alternaria alternata and Exophiala sp. were isolated from a monument in India (unpublished data). Coniosporium uncinatum MC557 was isolated from a Carrara marble statue located in the court-yard of the Messina Museum, Italy [9]. These isolated strains were kept in the collection of Department of Microbiological, Genetic and Molecular Sciences in Messina.

Alternaria alternata was cultivated in solid medium (Potato Dextrose Agar-PDA, Oxoid) for 5 days at $26^{\circ} \mathrm{C}$. Exophiala sp. and Coniosporium uncinatum were cultivated in liquid medium (Malt Extract Broth-MEB Oxoid) for 5 days at $26^{\circ} \mathrm{C}$.

Nutritive medium used for biodeterioration test is composed of $1 \times$ concentrated Yeast Nitrogen Broth (YNB) (Difco) plus the addition of Glucose $0.01 \%$. 


\section{III.3.2. Fungal units'suspension}

Fungal colonies growing in solid medium were scraped from the agar surface and conidia suspended in physiological solution (0.9\% of $\mathrm{NaCl}$ in distilled water), while the cultures in liquid medium were directly transferred in physiological solution. Each suspension was centrifuged $15 \mathrm{~min}$ at 2,095g (3,000 rpm with a Beckman and Coulter Allegra X-12R centrifuge-4750 A rotor). Centrifugation pellets were put in suspension in $1 \mathrm{ml}$ of physiological solution. The number of fungal units was determined through a direct microscopic count in a counting chamber (Bürker chamber, ProSciTech, Australia) and adjusted at a concentration of $8.7 \times 10^{5}$ fungal units $/ \mathrm{ml}$ in YNB $1 \times+$ glucose $0.01 \%$ medium.

\section{III.4. Biodeterioration test}

\section{III.4.1. Experimental set up}

Polyethylene boxes of $9.5 \times 9.5 \times 9.5 \mathrm{~cm}^{3}$ were used. In order to keep the humidity inside the box, the bottom was covered by vermiculite; paper sheet is disposed on it to avoid the direct contact between specimens and vermiculite. Boxes are autoclaved $15 \mathrm{~min}$ at $120^{\circ} \mathrm{C}$, then sterile water is added on vermiculite to wet it. Two specimens of each matrix were disposed in each box (Figure 2).

\section{III.4.2. Inoculation}

Each specimen was inoculated with $1.5 \mathrm{ml}$ of fungal units' suspension, except controls (only $1.5 \mathrm{ml}$ of sterile medium). Inoculation was performed in duplicate, thus for each strain, 6 specimens were inoculated ( 2 unweathered, 2 carbonated, 2 carbonated and leached), and placed in 3 different boxes. Boxes were incubated at $26^{\circ} \mathrm{C}$.

\section{III.4.3. SEM observation}

After 4 weeks of incubation, one specimen of each box was taken and broken in small pieces for SEM observation (Figure 3). Fixation of samples was performed overnight at $4^{\circ} \mathrm{C}$ in buffered aldehyde fixative 2\% (w/v) formaldehyde (P6148, Sigma). Samples were then washed 3 times in $0.01 \mathrm{M}$ phosphate buffer ( $0.01 \mathrm{M} \mathrm{NaH}_{2} \mathrm{PO}_{4} . \mathrm{H}_{2} \mathrm{O}$, o.01 $\mathrm{M} \mathrm{Na}_{2} \mathrm{HPO}_{4}, \mathrm{pH} 7.2$ ) for $10 \mathrm{~min}$ each. Dehydration was made in graded ethanol series $(70,85,95 \%(\mathrm{v} / \mathrm{v})$ and in anhydrous ethanol (100\%) for $15 \mathrm{~min}$ each). Samples were air dried and then coated with gold for SEM observation (JEOL 840 SEM).

\section{Results and discussion}

\section{IV.1. Accelerated weathering}

\section{IV.1.1. XRD analyses}

The assignments of the XRD peaks to phases were based on $2 \theta$ values and the corresponding d-spacing (Figure 4). The peaks corresponding to portlandite appear at 4.900, 3.112, 2.628, 1.927, 1.796, and $1.687 \AA$. The main peaks corresponding to ettringite are present at 9.671 , 5.583 , and $3.859 \AA$. Presence of calcite $\left(\mathrm{CaCO}_{3}\right)$ and gypsum can be observed but at a lower extent.

Additional peaks are noticed on the diffractogram of the carbonated specimen compared to non-weathered one. They are attributed to the formation of calcium carbonate polymorphsaragonite and vaterite-as a result of accelerated carbonation. The decrease in relative intensity of portlandite peaks is due to the dissolution of portlandite to form calcium carbonate. The presence of portlandite can be due to the fact that the depth investigated is larger than the carbonation front. The carbonation operation was performed for $48 \mathrm{~h}$, hence the specimen is only superficially carbonated. The diffractogram of the carbonated and leached specimen exhibits only calcite and aragonite peaks. The disappearance of portlandite and ettringite is a consequence of their dissolution as a result of leaching. Vaterite is the less stable calcium carbonate polymorph, and it is easily transformed into other forms.

\section{IV.1.2. FT-IR analyses}

Usually band assignments reported in literature are deducted from spectra performed in diffuse reflectance. In the present work, spectra acquisition is mainly performed in ATR. Band 
assignments on ATR spectrum are deducted from spectrum performed first in diffuse reflectance (Table 1).

A shift of about 10-20 wave number units is noted between both spectra (Figure 5). Nevertheless the band assignments for hydrated cement paste are in close agreement with those previously reported [20,40,43]. The band at $3,645 \mathrm{~cm}^{-1}$ is due to the $\mathrm{OH}$ band from $\mathrm{Ca}(\mathrm{OH})_{2}$ [42]. The water bands appear at approximately 3,440 (stretching) and 1,660 (bending) $\mathrm{cm}-1$ [41]. The bands at 1,480-1,430, 875 and $720 \mathrm{~cm}^{-1}$ are due to carbonates.

The wide and deep band between 1,480 and $1,430 \mathrm{~cm}^{-1}$ is attributed to $v_{3}$ of $\mathrm{CO}_{3}{ }^{2-}$ and the sharp bands at 875 and $720 \mathrm{~cm}^{-1}$ are due to $v_{2}$ and $v_{4}$ vibrations, respectively [41]. The band at $975 \mathrm{~cm}-1$ is due to the $\mathrm{Si}-\mathrm{O}$ asymmetric stretching band (v3) from C-S-H [40].

The spectral data changes upon weathering and analyses of these changes can provide valuable information about the reactions involved. The FT-IR data for band assignments are presented in Table 2. The $\mathrm{OH}$ band at $3,636 \mathrm{~cm}^{-1}$ from portlandite disappears with carbonation. However, XRD analyses show the presence of portlandite on carbonated specimen, but in small amounts. The majority of portlandite is mainly transformed during carbonation operation, and totally during leaching. The small amounts present on the carbonated specimen are probably not detectable with FT-IR, certainly due to smaller penetration depth of analysis on FT-IR compared to XRD.

The FT-IR spectra of weathered specimens (carbonated and leached or carbonated only) show a strong broad band at $1,414-1,440 \mathrm{~cm}^{-1}$, which is broader than the calcite band, characteristic of aragonite. According to the intensity it can be assumed that the aragonite overlays the calcite band. New bands appear at 1,080, 858, $702 \mathrm{~cm}^{-1}$ and are assigned to aragonite formed as a result of accelerated carbonation. The band at $742 \mathrm{~cm}^{-1}$ belonging to vaterite, appears only in the carbonated specimen. Other characteristic bands at 860, 850, and $710 \mathrm{~cm}^{-1}$ may be overlaid by calcite bands. Vaterite is a less stable polymorph of calcium carbonate and thereby transforms into more stable forms calcite and aragonite with leaching operation. The $\mathrm{Si}-\mathrm{O}$ stretching $\left(v_{3}\right)$ band now appears at approximately 970 and $980 \mathrm{~cm}^{-1}$ for the carbonated and carbonated then leached specimens respectively, while the same band in the non-weathered specimen appears at $959 \mathrm{~cm}^{-1}$. Hence, this shifting to higher frequency is caused by the polymerization of the orthosilicate units $\left(\mathrm{SiO}_{4}{ }^{4-}\right)$ during weathering process. The magnitude of this shift is indicative of the degree of polymerization [40].

\section{IV.1.3. SEM observations}

Figure 6 shows surface fractures. Platy crystals and fine needles are the distinguishing characteristic shapes of portlandite and ettringite respectively [15]. A thin layer covers progressively the specimen surface as accelerated weathering progresses. This is consistent with the weathering performed: carbonation results in a decrease in the amount of portlandite and the leaching gives rise to the dissolution of portlandite and ettringite. A net decrease in porosity is also observed: pores are progressively filled by $\mathrm{CaCO}_{3}$ precipitation and become smaller and smaller as the matrix is weathered.

Now, if one examines the following images of polished sections, microstructure alteration is not observed between non-weathered and carbonated specimens (Figure $7 \mathrm{a}, \mathrm{b}$ ). Contrarily, numerous cracks are observed for the carbonated and leached specimen (Figure 7c).

These cracks are distributed along the periphery (Figure 8). This phenomenon may be explained by one of two scenarios: (i) the cracks appear progressively during leaching operation, this could be confirmed by direct observation or (ii) the matrix structure is weakened by the leaching operation, and thereby the cracks are due to the sample preparation. We also notice for this sample the presence of a thin band which seems to be more porous than the rest of specimen (Figure 7c). Its thickness is estimated to be $70 \mu \mathrm{m}$.

\section{IV.1.4. SEM/EDX analyses}

Chemical change was expected from EDX analysis. Figure 9 presents EDX analysis performed on carbonated and leached specimens. Twenty punctual analyses are performed for each area; mean values are plotted on graphs. 
We compare concentrations in calcium, silicon, aluminium between analyses performed on the side and in the core. We assume that accelerated weathering has a superficial impact, so the chemical composition in the core is representative of a non-weathered matrix.

No change in chemical composition is observed, there is just a tendency of Ca enrichment and thereby Si depletion of specimen.

\section{IV.1.5. Discussion}

Our results show that accelerated carbonation results in calcite, vaterite and aragonite formation (Figure 4; Table 2). This is consistent with literature. The presence of metastable forms (vaterite and aragonite) in the carbonated area seems to be a feature of accelerated carbonation tests [54]. According to Thiery [53], the thermal stability of $\mathrm{CaCO}_{3}$ produced is lower as the carbonation level increases. This author also showed that the thermodynamically metastable forms of $\mathrm{CaCO}_{3}$ correspond to the carbonation of $\mathrm{C}-\mathrm{S}-\mathrm{H}$. The shift of the ${ }_{3} \mathrm{SiO}_{4}{ }^{4-}$ from the FT-IR spectrum (Table 2) to higher wave number units suggests also a polymerisation of $\mathrm{C}-\mathrm{S}-\mathrm{H}$ with the carbonation as well as with leaching operations [40].

The carbonation reaction mainly has two effects on the cement matrix and its pore water solution [6o]: lowering of the $\mathrm{pH}$ of the pore water, and decreasing of the matrix porosity. This is because of the formation of calcite, which is less dense than portlandite, thereby can clog pores more easily. Evolution of total porosity with carbonation is dependent of $\mathrm{w} / \mathrm{c}$ ratio and cement type.

Generally, the leaching of cement paste gives rise to matrix decalcification due to the dissolution of portlandite and $\mathrm{C}-\mathrm{S}-\mathrm{H}$ decalcification. Haga et al. [33] concluded from their work that the major leached constituents of hardened ordinary Portland cement are portlandite and $\mathrm{C}-\mathrm{S}-\mathrm{H}$ gel, and the large pore size, associated with the leaching of portlandite, will significantly affect the diffusion of leached constituents. In the present study leaching occurs after carbonation. The porosity decrease diminishes the leaching of matrix constituents, while the decrease in $\mathrm{pH}$ increases leaching. The effect of porosity, however, exceeds that of $\mathrm{pH}$, resulting in a net decrease of leaching due to carbonation [62]. It can be assumed that the dissolution of portlandite and decalcification of $\mathrm{C}-\mathrm{S}-\mathrm{H}$ result in $\mathrm{CaCO}_{3}$ precipitation in the pore volume. Gervais [26] found that carbonation prior to leaching operation results in a decrease of calcium release compared to the leaching of non-carbonated specimens. The mobility of $\mathrm{Ca}^{2+}$ is reduced, and it may precipitate with $\mathrm{CO}_{3}{ }^{2-}$ before, thus not reaching leachate. This could explain EDX analyses and lack of the matrix decalcification observed (Figure 9): most of the dissolved $\mathrm{Ca}^{2+}$ precipitates into $\mathrm{CaCO}_{3}$ before, hence not exiting the matrix with the outcome: enrichment in calcium near the specimen surface.

\section{IV.2. Biodeterioration test}

\section{$I V$.2.1. Observations of non-weathered specimens}

Figure 10 presents direct observations of the non-weathered specimens performed after 4 weeks of incubation. No microbial growth is noticed on all exposed specimen. Coniosporium uncinatum cells are dark pigmented and taller than those of other fungi inoculated. Hence, this results in the presence of black spots on the specimen. Moreover, when the suspension of cells is inoculated on the non-weathered specimens, it does not penetrate immediately into the matrix. Thus, cells can agglomerate on the surface, resulting in observation of black spots. This spots are, in this case, absolutely not due to the fungal development.

\section{IV.2.2. Observations of carbonated specimens}

Figure 11 shows direct observations performed on the carbonated specimens just after inoculation (To) and after 4 weeks of incubation (T4). No microbial growth is noted on the control and specimens inoculated with Exophiala sp. A fungal development is observed on one specimen inoculated with Coniosporium uncinatum. It appears after 3 weeks of incubation and looks like small dark area of about $1 \mathrm{~cm}$ diameter. Nevertheless, it doesn't seem to be characteristic of Coniosporium uncinatum development, but looks more like Alternaria alternata. While boxes are handled with lot of care, they remain very close during experiment, so a fungal contamination can easily occur. This should be confirmed with 
microscopic observations. Interesting results are obtained with the specimens inoculated with Alternaria alternata. Therefore, a fungal development is noticed after 1 week only of incubation for one specimen.

For the second specimen inoculated, it appears after 3 weeks of incubation. The fungus grows until the fourth week. It appears as dark area, scarcely spread on the specimen surface. Hydrated cement paste are heterogeneous material, and there are likely to exist micro-regions that could be prone to preferential fungal colonisation due to e.g. differences in the carbonation rate. Differences in specimen porosity would lead to different rates of $\mathrm{CO}_{2}{ }^{-}$ ingress, which in turn would produce varying degree of carbonation. This would result in differences in the $\mathrm{pH}$ values in the micro-niches, thus influencing fungal growth [49]. The fungal spreading may also reflect the distribution of fungal cells on the specimen surface after inoculation.

\section{$I V .2 .3$. Observations of the carbonated then leached specimens}

Figure 12 presents direct observations performed on the carbonated then leached specimens. Microbial development is noticed on all the specimens after 1 week of incubation only. For the specimens inoculated with Exophiala sp. and surprisingly also controls, it appears due to pink coloured spots which seem to grow along the specimen cracks. It is certainly due a bacterial contamination. Moreover, the specimens were inoculated in two series with 1 day of interval: firstly inoculation with Exophiala sp., and controls were performed, then the day after with Alternaria alternata and Coniosporium uncinatum. The bacterial contamination occurred probably during the inoculation of the first series. Nevertheless, this contamination remains localized on restricted area and doesn't spread all over the surface.

Exophiala sp. growth is noticed after the first week on both specimens inoculated. The bacterial contamination doesn't seem to prevent the fungal development. The growth is more pronounced on the periphery area of the specimen surface. No microbial element is observed on the SEM examination of the cross sections.

Alternaria alternata development is observed since the first week of incubation. It is characterized first with mycelial development and then sporulation is observed on the surface. The growth appears more homogeneously than for the carbonated only specimens. SEM observations point out numerous hyphae on the surface (Figure 13a). Crystals, plates like, resulting probably from the sample preparation, are noted from observations of the specimen surface. The cross-section observations show also hyphae but in a more dispersed way (Figure 13b). It may be explained by the fact that fungi can penetrate inside the matrix only by the open porosity, provided the pore diameter is large enough, or through the existing cracks. Therefore, the space available for the fungal growth inside the matrix does not permit extensive development. Nevertheless, the resulting biodeterioration could be more intense inside the exposed material than on the surface.

The development of Coniosporium uncinatum is observed since the first week of incubation. It is characterized by the increase of the number and the size of the black spots. Mycelial growth is noted as the incubation time increases. The development seems to occur all over the surface, rather homogeneously. SEM pictures of the surface exhibit the hyphae spread on all over the surface (Figure 13c). Moreover, hyphae are closely linked to the matrix, and even seem to penetrate inside it. Examinations of the cross-section (Figure 13d) clearly show hyphal penetration into the matrix through cracks. It points out the capacity of the fungi to develop not only superficially but also inside the matrix, via structural default, accentuating the physical deterioration.

\section{IV.2.4. Discussion}

The results point out that in the present study the microbial growth is promoted with the accelerated weathering of the matrix. It plays a major role. Decrease of surface $\mathrm{pH}$ increases considerably matrix bioreceptivity. The microbial colonisation is observed on some carbonated specimens and on all carbonated then leached specimens. Carbonation is the most common chemical reaction influencing cement-based materials in natural environmental scenarios $[26,38]$. This is the reason why accelerated weathering of matrix is generally 
performed by carbonation [10, 26, 49]. But cement based materials are also exposed to the elements (humidity, acidic rain, snow...) which leads to cement compounds leaching [4]. In our case, carbonation is followed by leaching operation. This allows to obtain a surface $\mathrm{pH}$ about 8.8 after 30 days (data not shown), but also to have two ways of weathering involved in natural weathering of materials. To our knowledge, only Escadeillas et al. [19] and de Muynck et al. [11] performed these two ways of accelerated weathering of the matrix, but giving greater importance to the carbonation step.

Physical weathering of a mineral substrate acts to enhance or accelerate rates of chemical, biomechanical and biochemical weathering and vice versa. The development of cracks, fissures and weathering rinds in rocks accelerates biological weathering by providing a niche that can easily be exploited by opportunistic micro-organisms [5].

The presence of Alternaria alternata and Coniosporium uncinatum, two melanin producers, was noted on the SEM observations of the cross-sections. Melanin pigmentation of rockinhabiting fungi confers extra-mechanical strength to the hyphae that are then better able to grow into crevices $[17,30,52]$. Increased penetration augments contact of fungal hyphae and their metabolites with the rock, amplifying their geochemical influence on the mineral substrate. Expansion of hyphal growth into deeper rock layers also helps to protect the cells from the UV radiation [30]. One characteristic of meristematic fungi is the ability to form filamentous hyphae that develop from clump-like colonies to penetrate deep into rocks thus protecting themselves from environmental stresses. In this sense, the visible portion of melanized micro colonial fungi is like the tip-of-the-iceberg, because the hyphae can rapidly penetrate several $\mathrm{mm}$ to $\mathrm{cm}$ into hard rocks in search of more protected environments [30]. The fungi form explorative hyphae to seek nutrients on the surface, or mycelium during the growth. Under natural conditions, nutrient availability, even if small, enhances the chance of fungal units (single cells, conidia, or hyphae fragments) surviving and starting the colonization $[55,56]$.

\section{Conclusion}

Results showed that there was no microbial development when the cementitious matrix was not weathered. Microbial growth was noted on and inside the carbonated then leached specimens.

Relating to the matrix weathering; combined process led to the maximum microbial growth. This process was composed by a carbonation operation followed by the leaching of the matrix. This resulted in modification of the matrix microstructure and above all in the surface $\mathrm{pH}$ decrease. Carbonation of hardened cement paste led to a surface composition nearer of a limestone than that of a cementitious matrix.

The accelerated laboratory test developed in this study permits to obtain a rapid fungal development on cement specimens. Three months of experiments only are needed to obtain first results, which is rather shorter than other test developed to date to study fungal biodeterioration. Results are mainly related to aesthetical biodeterioration. Moreover, fungal strains presenting various growth patterns were used, and so may lead to different biodeterioration mechanisms in long term exposition experiment. These results will be completed by the quantification and estimation of the extent of the fungal growth.

This test could be used to compare the bioreceptivity of various cement based materials, leading to results in 3 months only.

\section{Acknowledgments}

Authors would like to thank Patrick Dégrugilliers (Ecole des Mines de Douai, Civil Engineering Department) for the preparation of thin section. Authors acknowledge Clara Urzi and Filomena De Leo (Messina University, Department of Microbiology, Genetic and Molecular Sciences) for their precious help of the microbiology part of the study. 


\section{References}

[1] Allsopp C, Allsopp D, Gaylarde CC (2004) Introduction to biodeterioration, 2nd edn. Cambridge University Press, Cambridge. ISBN 0-521-52887-9

[2] Anstice DJ, Page CL, Page MM (2005) The pore solution phase of carbonated cement pastes. Cem Concr Res 35:377-383

[3] Barberousse H (2006) Etude de la diversité des algues et des cyanobactéries colonisant les revêtements de façade en France et recherche des facteurs favorisant leur implantation. PhD thesis, Muséum National d'Histoire Naturelle, pp 186

[4] Barbieri-Albert B (2002) Altération de matrices cimentaires par des eaux de pluie et des eaux sulfatées: approche expérimentale et thermodynamique. $\mathrm{PhD}$ thesis, Ecole Nationale Supérieure des Mines de Saint-Etienne and Institut National Polytechnique de Grenoble, pp 294

[5] Burford EP, Fomina M, Gadd GM (2003) Fungal involvement in bioweathering and biotransformation of rocks and minerals. Miner Mag 67:1127-1155

[6] de Hoog GS (1993) Evolution of black yeasts: possible adaptation to human host. Antonie van Leeuwenhoek 63:105-109

[7] de la Torre MA, Gomez-Alarcon G, Melgarejo P, Saiz-Jimenez C (1991) Fungi in weathered sandstone from Salamanca cathedral, Spain. Sci Total Environ 107:159-168

[8] De Leo F, Urzì C (2003) Fungal colonization on treated and untreated stone surfaces. In: Saiz-Jimenez (ed) Molecular biology and cultural heritage. Swets \& Zeitlinger BV, Lisse, pp 213-218

[9] De Leo F, Urzì C, de Hoog GS (1999) Two Coniosporium species from rock surfaces. Stud Mycol 43:70-79

[10] De Moraes Pinheiro SM, Ribas Silva M (2003) Alteration of concrete microstructure by biodeterioration mechanisms. In: Ribas Silva M (ed) Proceedings pro044: microbial impact on building materials, Lisbon, Portugal, pp 48-57

[11] De Muynck W, Maury Ramirez A, De Belie N, Verstraete W (2009) Evaluation of strategies to prevent algal fouling on white architectural and cellular concrete. Int Biodeterior Biodegrad 63:679-689

[12] Devarajan A, Khadar MA, Chattopadhay K (2007) Effect of ball milling on chemically synthesized nanoparticles of CaCO3. Mater Sci Eng A 452-453:395-400

[13] Dewaele PJ, Reardon EJ, Dayal R (1991) Permeability and porosity changes associated with cement grout carbonation. Cem Concr Res 21:441-454

[14] Diakumaku E, Gorbushina AA, Krumbein WE, Panina L, Soukharjevski S (1995) Black fungi in marble and limestones-an aesthetical, chemical and physical problem for the conservation of monuments. Sci Total Environ 167:295-304

[15] Diamond S (1976) Cement paste microstructure-an overview at several levels. In: Cement and Concrete Association (eds) Proceeding of the conference on hydraulic cement paste: their structure and properties, Sheffield University, pp 2-30

[16] Diamond S (2000) Mercury porosimetry: an inappropriate method for the measurement of pore size distributions in cement-based materials. Cem Concr Res 30:1517-1525

[17] Dornieden Th, Gorbushina AA, Krumbein WE (2000) Biodecay of cultural heritage as a space/time-related ecological situation-an evaluation of a series of studies. Int Biodeterior Biodegrad 46:261-270

[18] Dubosc A (2000) Etude du développement de salissures biologiques sur les parements en béton: mise au point d'essais accélérés de vieillissement. $\mathrm{PhD}$ thesis, Institut National des Sciences Appliquées de Toulouse, pp 250

[19] Escadeillas G, Bertron A, Blanc G, Dubosc A (2007) Accelerated testing of biological stain growth on external concrete walls. Part 1: Development of the growth tests. Mater Struct 40:1061-1071

[20] Farcas F, Touze P (2001) La spectrométrie infrarouge à transformée de Fourier (IRTF): Une méthode intéressante pour la caractérisation des ciments. Bull Lab Ponts Chaussées 230:77-88 
[21] Fattuhi NI (1988) Concrete carbonation as influenced by curing regime. Cem Concr Res 18:426-430

[22] Faucon P, Adenot F, Jorda M, Cabrillac R (1997) Behaviour of crystallised phases of Portland cement upon water attack. Mater Struct 30:480-485

[23] Faucon P, Adenot F, Jacquinot JF, Petit JC, Cabrillac R, Jorda M (1998) Long-term behaviour of cement pastes used for nuclear waste disposal: review of physico-chemical mechanisms of water degradation. Cem Concr Res 28:847-857

[24] Garcia-Valles M, Vandrell-Saz M, Krumbein WE, Urzì C (1997) Coloured mineral coatings on monument surfaces as a result of biomineralization: the case of the Tarragona cathedral (Catalonia). Appl Geochem 12:255-266

[25] Garrabrants AC, Sanchez F, Kosson DS (2004) Changes in constituent equilibrium leaching and pore water characteristics of a Portland cement mortar as a result of carbonation. Waste Manag 24:19-36

[26] Gervais C (1999) Evaluation environnementale des perspectives de valorisation en BTP de scories de première fusion de plomb et de zinc. PhD thesis, Institut National des Sciences Appliquées de Lyon, pp 218

[27] Gervais C, Garrabrants AC, Sanchez F, Barna R, Moszkowicz P, Kosson DS (2004) The effects of carbonation and drying during intermittent leaching on the release of inorganic constituents from a cement-based matrix. Cem Concr Res 34:119-131

[28] Ghosh SN (2001) IR spectroscopy. In: Ramashandran VS, Beaudoin JJ (eds) Handbook of analytical techniques in concrete science and technology-principles, techniques, and applications. William Andrew Publishing/Noyes, Ottawa, Canada, pp 174-204

[29] Glasser FP, Marchand J, Samson E (2008) Durability of concrete-degradation phenomena involving detrimental chemical reactions. Cem Concr Res 38:226-246

[30] Gorbushina AA (2007) Life on rocks. Environ Microbiol 9(7):1613-1631

[31] Guillitte O (1995) Bioreceptivity: a new concept for building ecology studies. Sci Total Environ 167:215-220

[32] Guillon E (2004) Durabilité des matériaux cimentaires-Modélisation de l'influence des équilibres physico-chimiques sur la microstructure et les propriétés mécaniques résiduelles. PhD thesis, Ecole Normale Superieures de Cachan, pp 154

[33] Haga K, Sutou S, Hironaga M, Tanaka S, Nagasaki S (2005) Effects of porosity on leaching of Ca from hardened ordinary Portland cement paste. Cem Concr Res 35:17641775

[34] Hidalgo A, Petit S, Domingo C, Alonso C, Andrade C (2007) Microstructural characterization of leaching effects in cement pastes due to neutralisation of their alkaline nature: part I: Portland cement pastes. Cem Concr Res 37:63-70

[35] Khatib JM, Mangat PS (2003) Porosity of cement paste cured at $45^{\circ} \mathrm{C}$ as a function of location relative to casting position. Cem Concr Compos 25:97-108

[36] Klemm WA, Berger RL (1972) Accelerated curing of cementitious systems by carbon dioxide: part I. Portland cement. Cem Concr Res 2:567-576

[37] Lange LC, Hills CD, Poole AB (1997) Effect of carbonation on properties of blended and non-blended cement solidified waste forms. J Hazard Mater 52:193-212

[38] Macias A, Kindness A, Glasser FP (1997) Impact of carbon dioxide on the immobilization potential of cemented wastes: chromium. Cem Concr Res 27:215-225

[39] Mollah MYA, Hess TR, Tsai YN, Cocke DL (1993) An FTIR and XPS investigations of the effects of carbonation on the solidification stabilization of cement-based systemsPortland type V with zinc. Cem Concr Res 23:773-784

[40] Mollah MYA, Palta P, Hess TR, Vempati RK, Cocke DL (1995) Chemical and physical effects of sodium lignosulfonate superplasticizer on the hydration of Portland cement and solidification/stabilization consequences. Cem Concr Res 25:671-682

[41] Mollah MYA, Lu F, Cocke DL (1998) An X-ray diffraction (XRD) and Fourier transform infrared spectroscopic (FT-IR) characterization of the speciation of arsenic (V) in Portland cement type-V. Sci Total Environ 224:57-68 
[42] Mollah MYA, Yu M, Schennach R, Cocke DL (2000) A Fourier transform infrared spectroscopic investigation of the early hydration of Portland cement and the influence of sodium lignosulfonate. Cem Concr Res 30:267-273

[43] Mollah MYA, Kesmez M, Cocke DL (2004) An X-ray diffraction (XRD) and Fourier transform infrared spectroscopic (FT-IR) investigation of the long-term effect on the solidification/stabilization $(\mathrm{S} / \mathrm{S})$ of $\operatorname{arsenic}(\mathrm{V})$ in Portland cement type-V. Sci Total Environ 325:255-262

[44] Ngala VT, Page CL (1997) Effects of carbonation on pore structure and diffusional properties of hydrated cement pastes. Cem Concr Res 27:995-1007

[45] Nielsen KF, Holm G, Uttrup LP, Nielsen PA (2004) Mould growth on building materials under low water activities. Influence of humidity and temperature on fungal growth and secondary metabolism. Int Biodeterior Biodegrad 54:325-336

[46] Oshima A, Matsui I, Yuasa N, Henmi Y (1999) A study on growth of fungus and algae on mortar. Trans Jpn Concr Inst 21:173-178

[47] Saiz-Jimenez C (1997) Biodeterioration vs biodegradation: the role of microorganisms in the removal of pollutants deposited on historic buildings. Int Biodeterior Biodegrad 40:225-232

[48] Sanchez F, Gervais C, Garrabrants AC, Barna R, Kosson DS (2002) Leaching of inorganic contaminants from cement-based waste materials as a result of carbonation during intermittent wetting. Waste Manag 22:249-260

[49] Shirakawa MA, Beech IB, Tapper R, Cinotto MA, Gambale W (2003) The development of a method to evaluate bioreceptivity of indoor mortar plastering to fungal growth. Int Biodeterior Biodegrad 51:83-92

[50] Simpson LJ (1998) Electrochemically generated $\mathrm{CaCO}_{3}$ deposits on iron studied with FTIR and Raman spectroscopy. Electrochim Acta 43:2543-2547

[51] Sterflinger K (1995) Geomicrobiological investigations on the alteration of marble monuments by dematiaceous fungi (Sanctuary of Delos, Cyclades, Greece). PhD thesis, University of Oldenburg, pp 138

[52] Sterflinger K, Krumbein WE (1997) Dematiaceous fungi as a major agent for biopitting Mediterranean marbles and limestones. Geomicrobiol J 14(3):219-230

[53] Thiery M (2005) Modélisation de la carbonatation atmosphérique des matériaux cimentaires ; Prise en compte des effets cinétiques et des modifications microstructurales et hydriques. PhD thesis, Ecole Nationale des Ponts et Chaussées, pp 304

[54] Thiery M, Villain G, Dangla P, Platret G (2007) Investigation of the carbonation front shape on cementitious materials: effects of the chemical kinetics. Cem Concr Res 37:1047-1058

[55] Urzì C, De Leo F (2001) Sampling with adhesive tape strips: an easy and rapid method to monitor microbial colonization on monument surfaces. J Microbiol Meth 44:1-11

[56] Urzì C, De Leo F (2007) Evaluation of the efficiency of water-repellent and biocide compounds against microbial colonization of mortars. Int Biodeterior Biodegrad 60:2534

[57] Urzì C, Realini M (1998) Colour changes of Notos calcareous sandstone as related to its colonisation by microorganisms. Int Biodeterior Biodegrad 42:45-54

[58] Urzì C, De Leo F, de Hoog GS, Sterflinger K (2000) Recent advances in the molecular biology and ecophysiology of meristematic fungi. In: Ciferri O, Tiano P, Mastromei G (eds) Proceeding of the international congress on microbes and art, pp 3-19

[59] Valls S, Vasquez E (2001) Accelerated carbonation of sewage sludge-cement-sand mortars and its environmental impact. Cem Concr Res 31:1271-1276

[6o] Van Gerven T, Moors J, Dutre V, Vandecasteele C (2004) Effect of CO2 on leaching from a cement-stabilized MSWI fly ash. Cem Concr Res 34:1103-1109

[61] Van Gerven T, Van Baelen D, Dutre D, Vandecsteele C (2004) Influence of carbonation and carbonation methods on leaching of metals from mortars. Cem Concr Res 34:149156 
[62] Van Gerven T, Cornelis G, Vandoren E, Vandecasteele C (2007) Effects of carbonation and leaching on porosity in cement-bound waste. Waste Manag 27:977-985

[63] Warscheid T, Braams J (2000) Biodeterioration of stone: a review. Int Biodeterior Biodegrad 46:343-368

[64] Wiktor V, Grosseau P, Guyonnet R, Garcia-Diaz E (2006) Biodétérioration d'une matrice cimentaire par les champignons: influence du vieillissement accéléré sur le développement fongique. Matériaux Tech 94:507-515

[65] Wollenzien U, de Hoog GS, Krumbein WE, Urzì C (1995) On the isolation of microcolonial fungi occurring on and in marble and other calcareous rocks. Sci Total Environ 167:287-294 


\section{Figures}

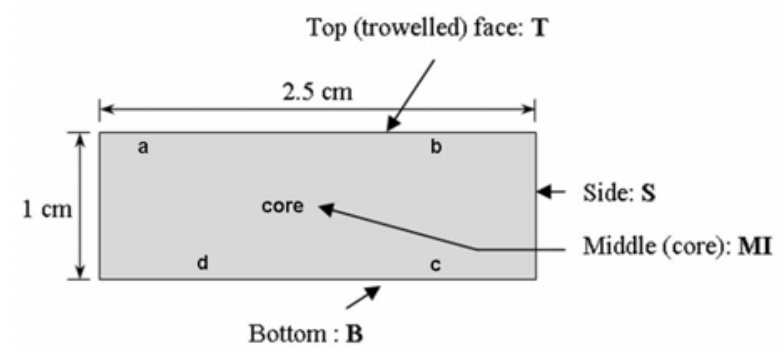

Figure 1: Localization of EDX analyzed areas.

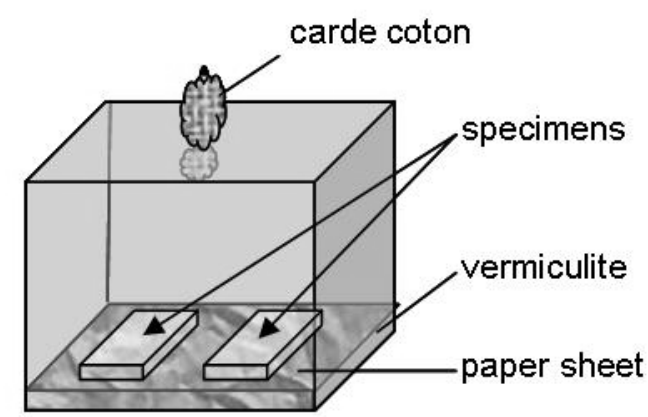

Figure 2: Experimental set up for the biodeterioration test.

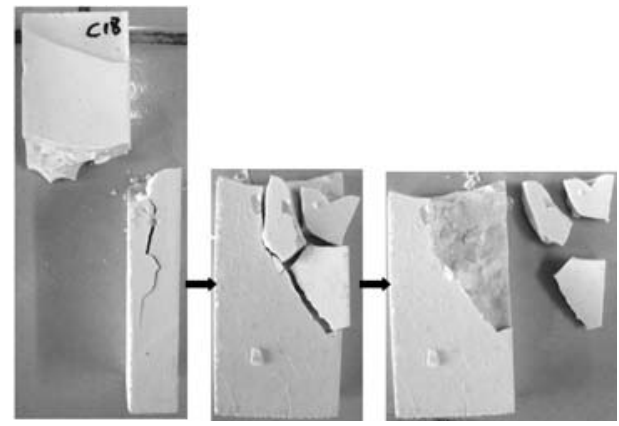

Figure 3: Example of a specimen broken to carry out SEM observations. 
Materials and Structures, 2010, doi: 10.1617/s11527-010-96.53-1
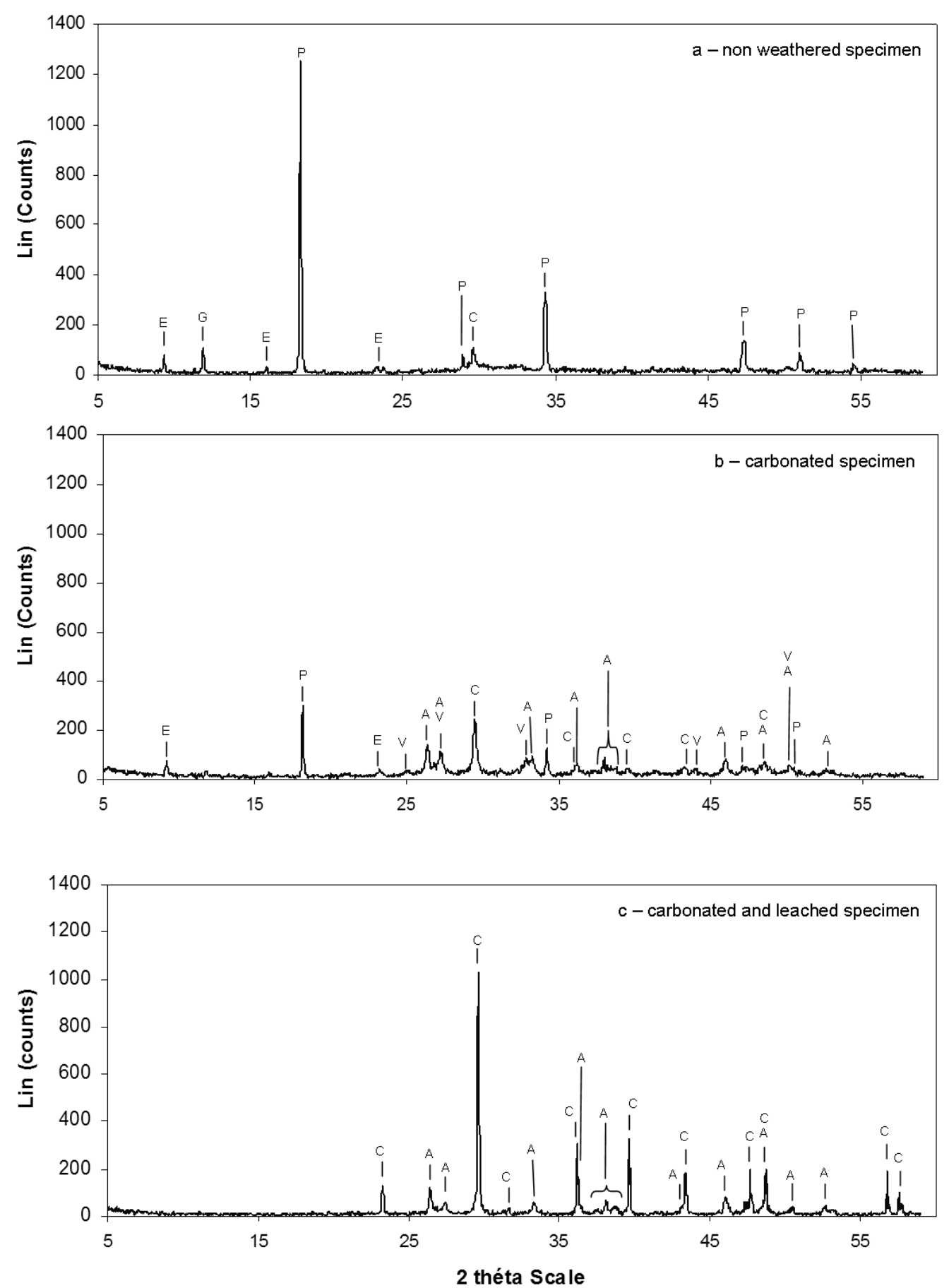

Figure 4: $X$-ray diffractogram of specimens before (a) and after (b), (c) accelerated weathering of the matrix $E=$ ettringite, $G=$ gypsum, $P=$ portlandite, $C=$ calcite, $A=$ aragonite, $V=$ vaterite. 
Materials and Structures, 2010, doi: 10.1617/s11527-010-96.53-1
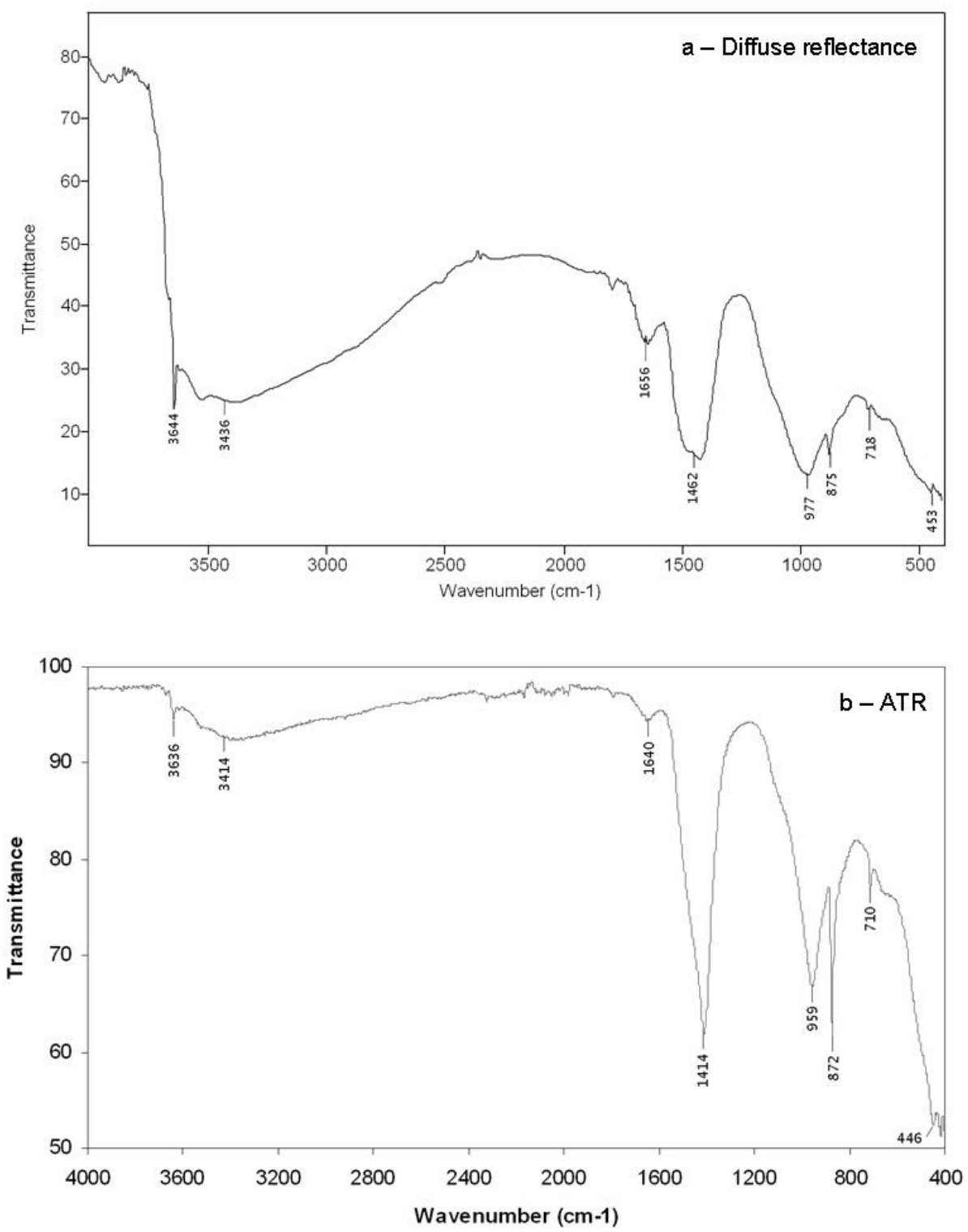

Figure 5: FT-IR spectra of hydrated cement paste at 28 days of curing at 100\%RH - (a) diffuse reflectance, (b) ATR. 

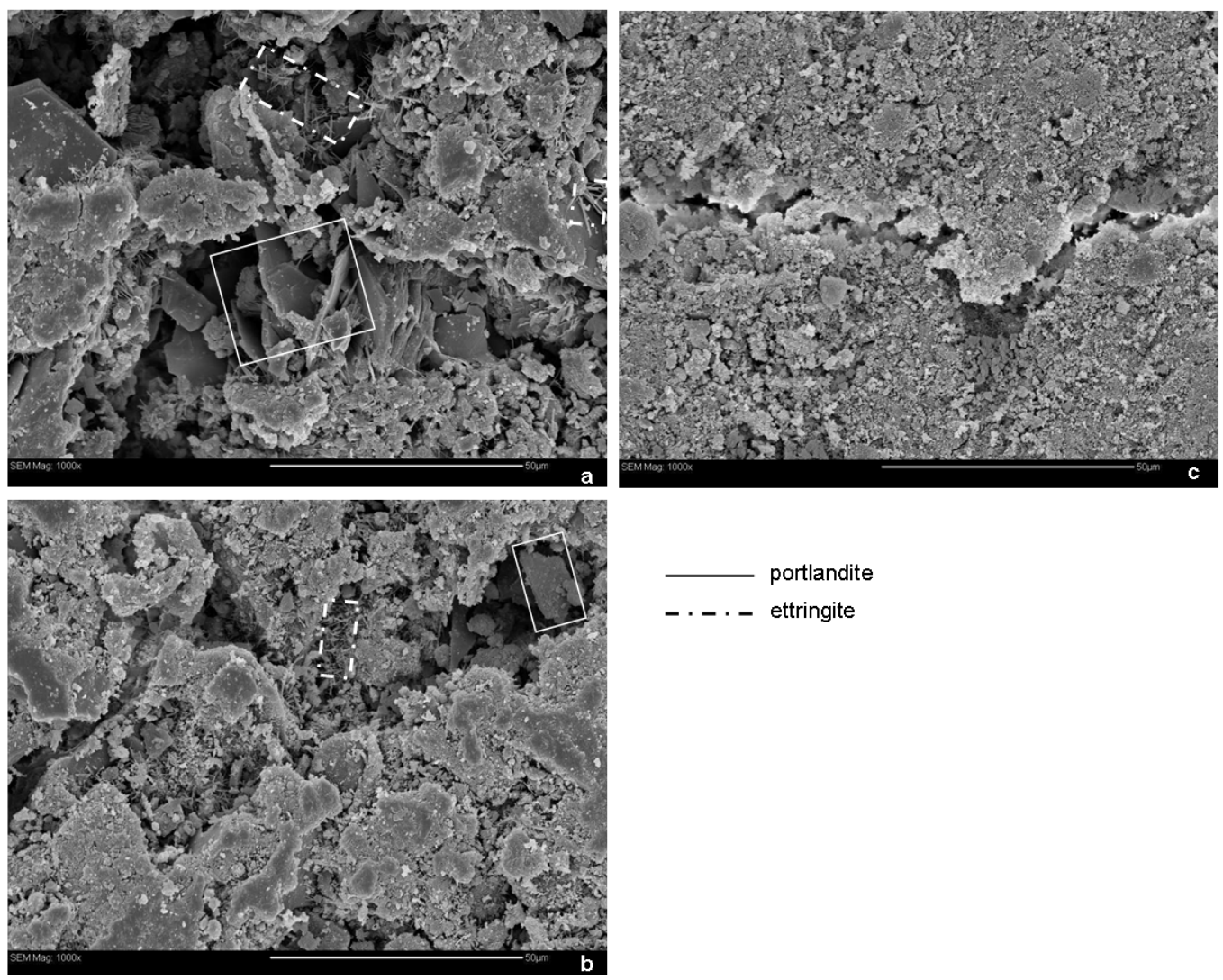

Figure 6: SEM images of surface fractures of specimens - (a) non weathered, (b) carbonated, (c) carbonated then leached.
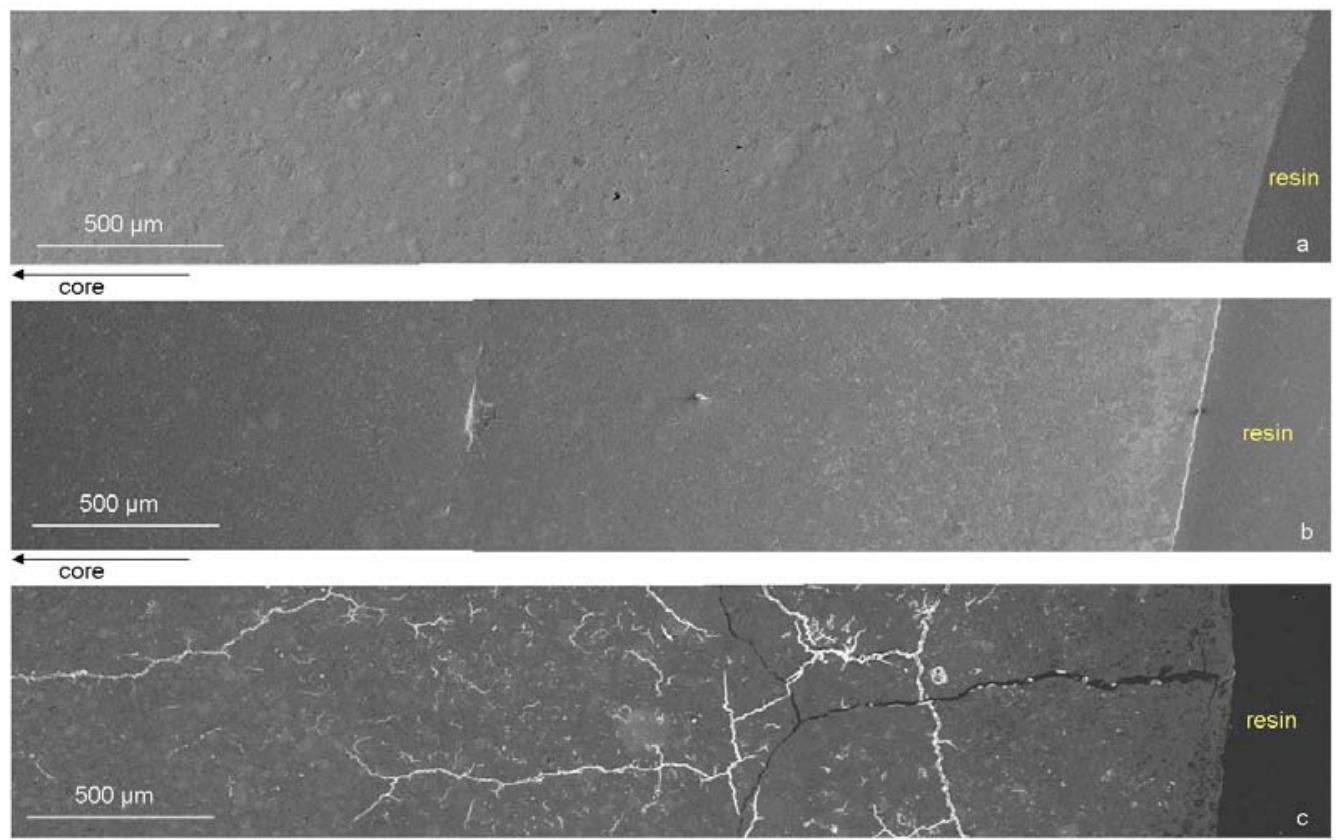

Figure 7: SEM images of polished sections for specimens (a) non weathered, (b) carbonated, (c) carbonated then leached. 
Materials and Structures, 2010, doi: 10.1617/s11527-010-9653-1

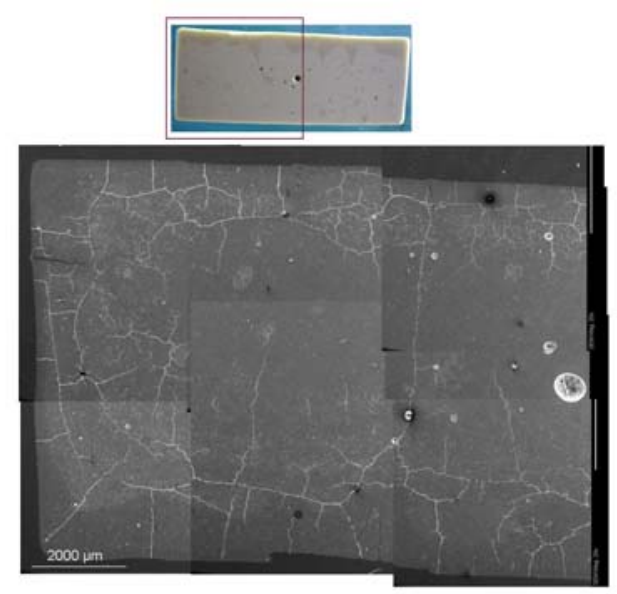

Figure 8: Global SEM images of polished sections of a carbonated then leached specimen.
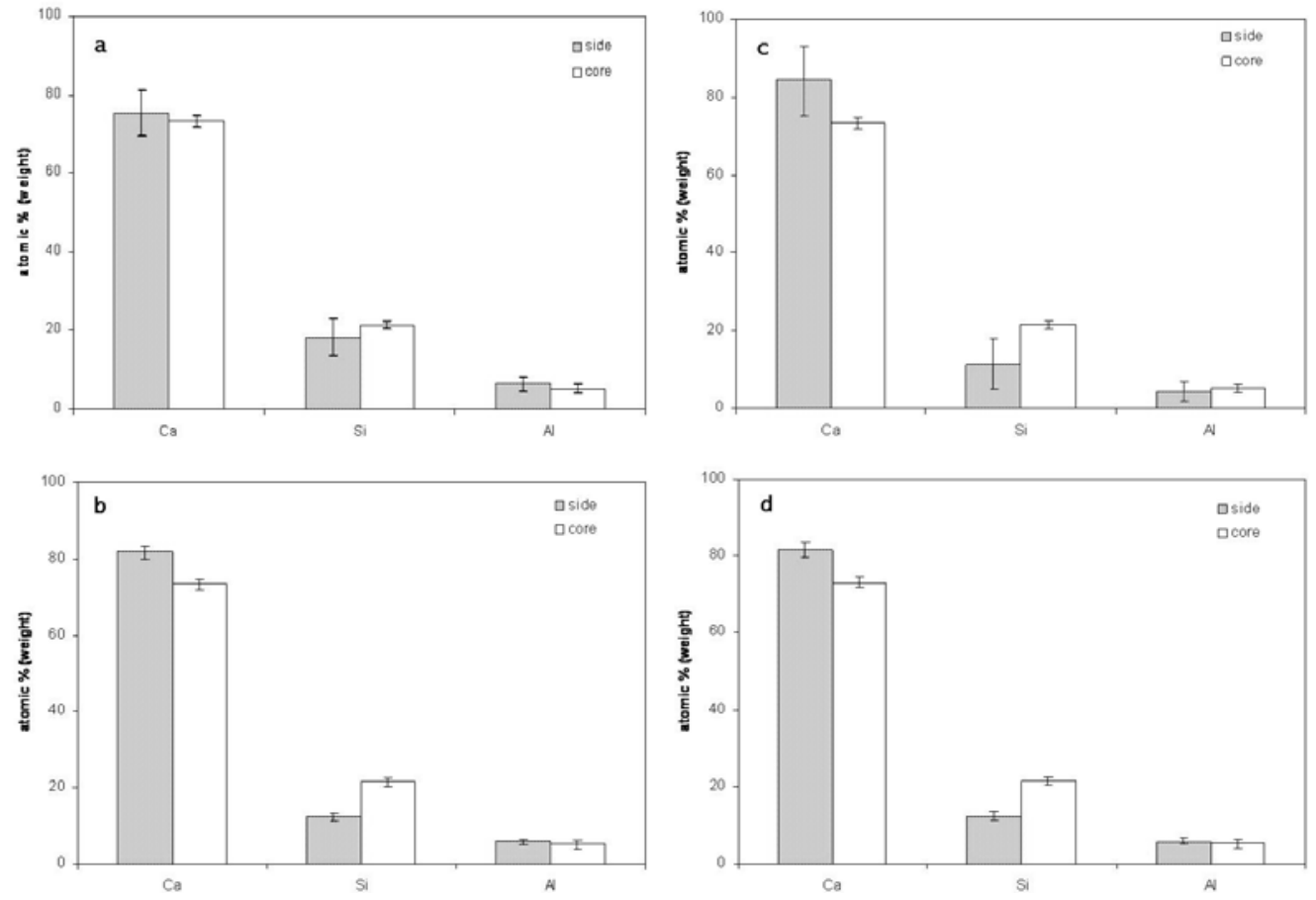

Figure 9: SEM/EDX analyses of polished sections for carbonated then leached specimen - $a, b, c, d$ correspond to the analyzed areas named in section III.2.3. 

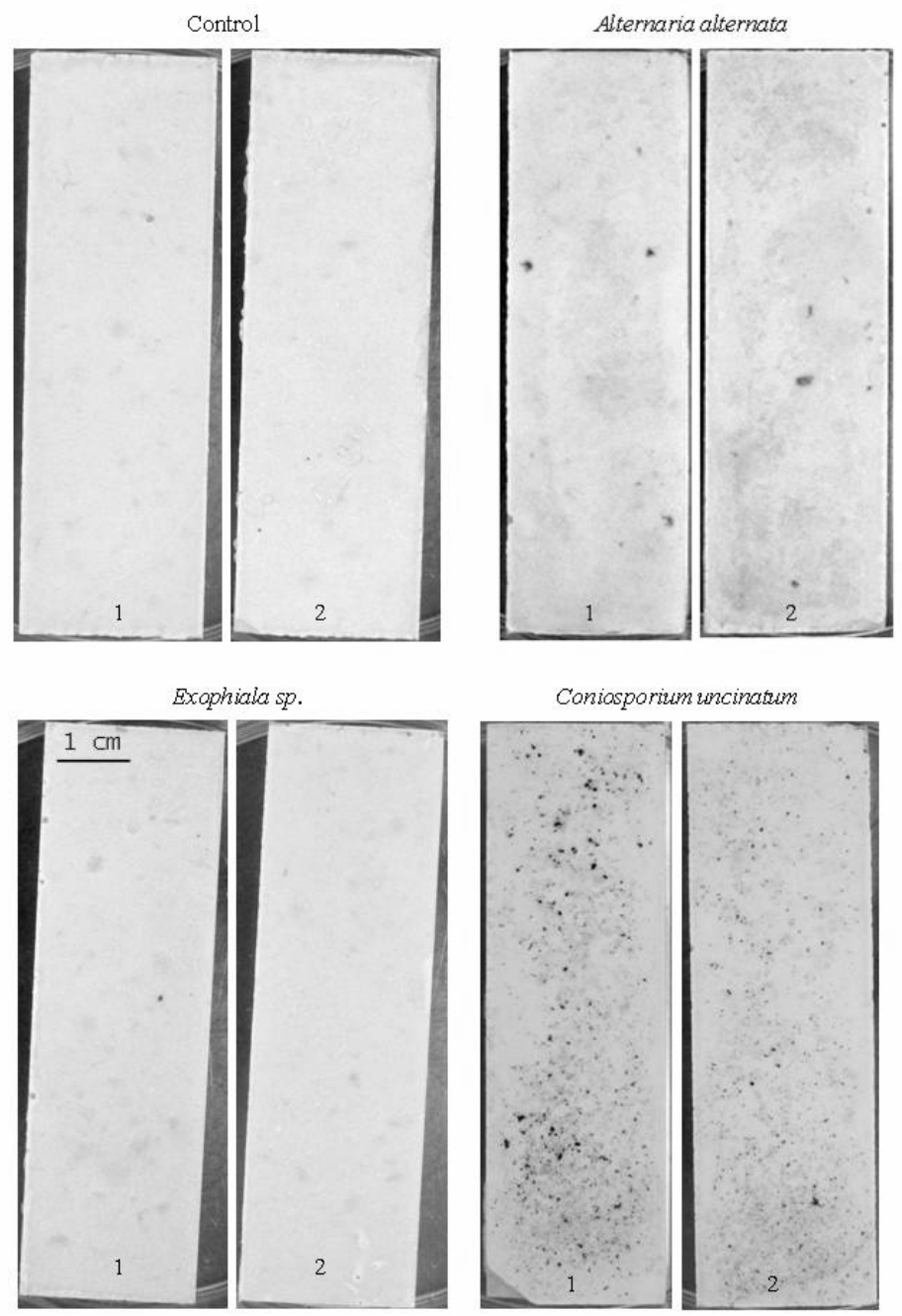

Figure 10: Direct observations of the non weathered specimens after 4 weeks of incubation. 
Materials and Structures, 2010, doi: 10.1617/s11527-010-965.3-1

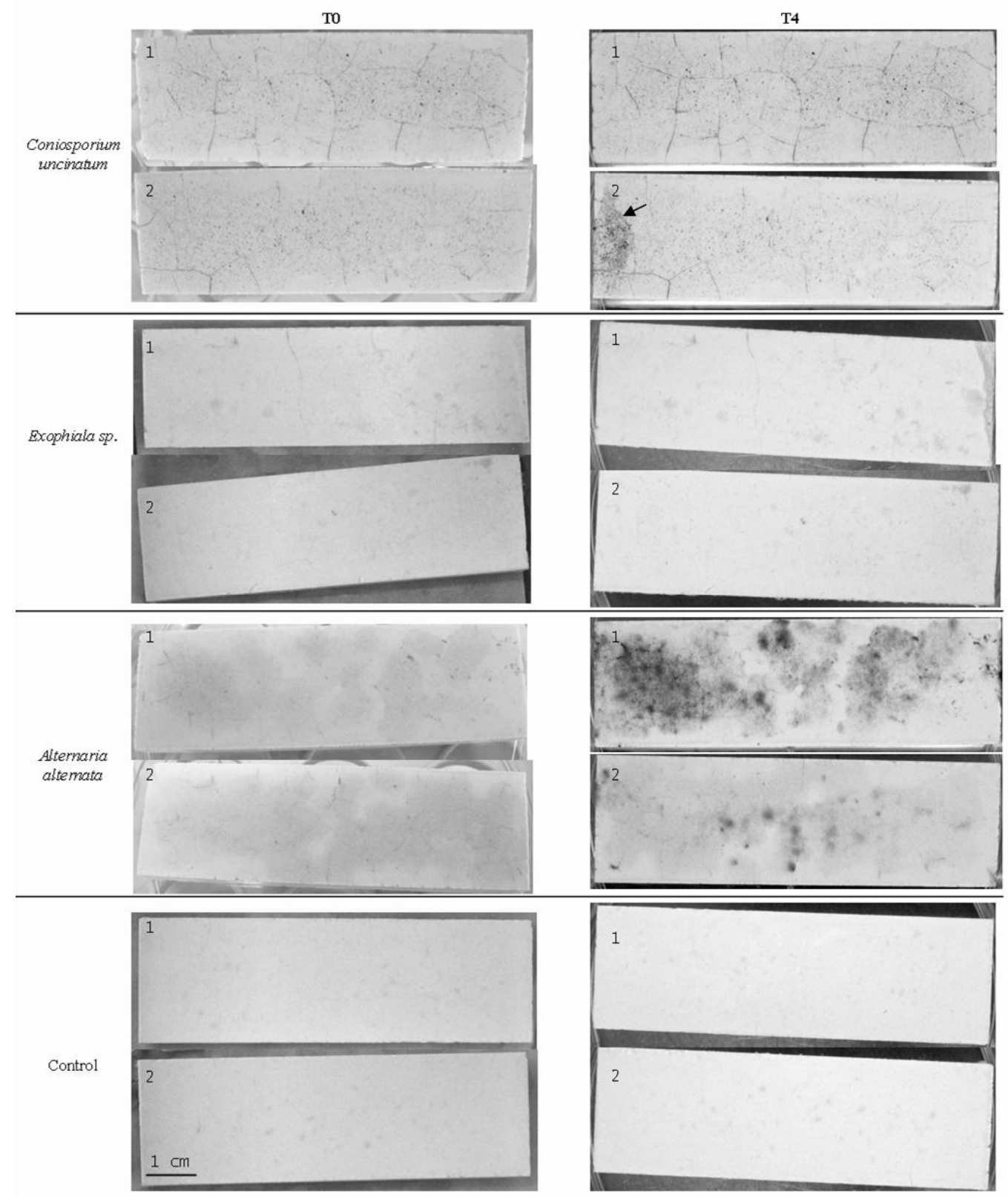

Figure 11: Direct observations of the carbonated specimens - arrow indicates contamination. 
Materials and Structures, 2010, doi: 10.1617/s11527-010-965.3-1

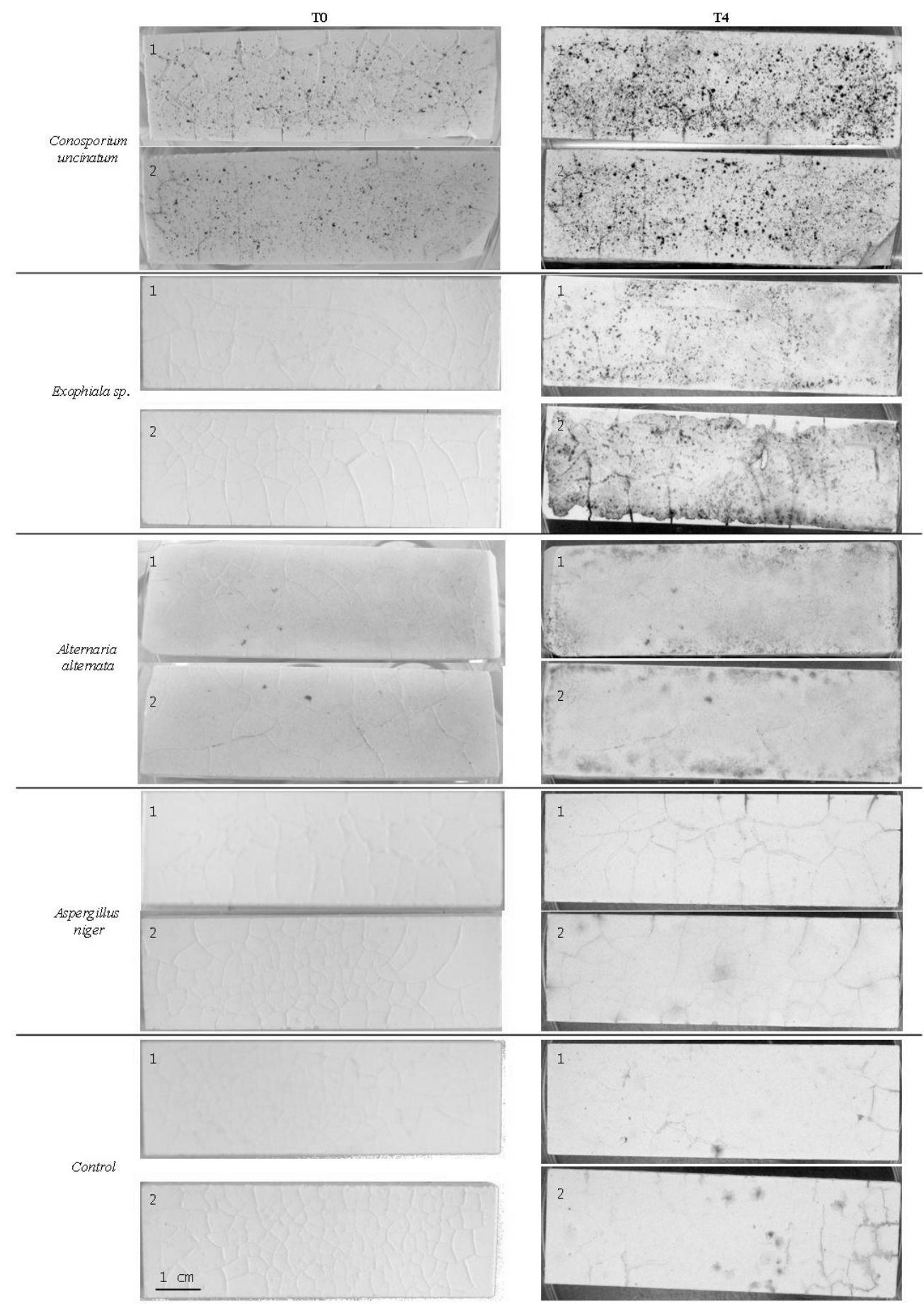

Figure 12: Direct observations of the carbonated then leached specimens. 

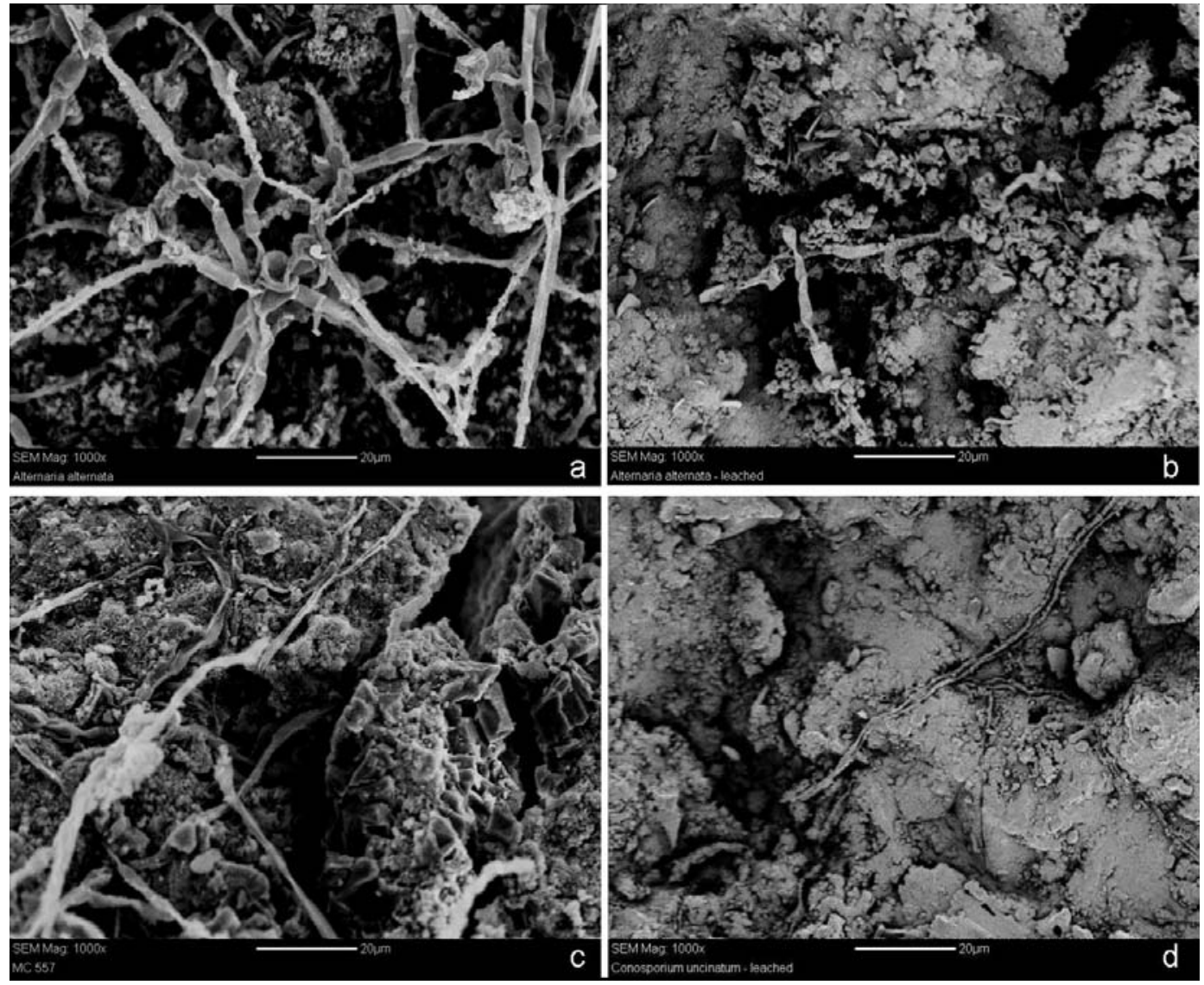

Figure 13: SEM observations of the carbonated then leached specimens - Surface (a) and cross-section (b) of specimens inoculated with Alternaria alternata - Surface (c) and cross-section (d) of specimen inoculated with Coniosporium uncinatum. 


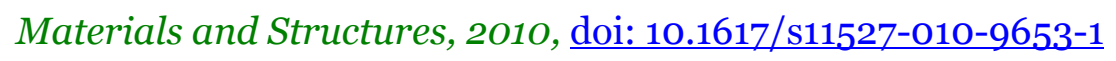

\section{Tables}

Table 1: FT-IR characterization of hydrated cement paste.

\begin{tabular}{|c|c|c|c|c|}
\hline Band assignments & $\begin{array}{l}\text { Hydrated cement } \\
1 \text { month }\left(\mathrm{cm}^{-1}\right)\end{array}$ & $\begin{array}{l}\text { Hydrated cement } \\
\text { after mixing }\left(\mathrm{cm}^{-1}\right)\end{array}$ & $\begin{array}{l}\text { Hydrated cement } \\
\text { paste }\left(\mathrm{cm}^{-1}\right)\end{array}$ & $\begin{array}{l}\text { Hydrated cement } \\
\text { paste }\left(\mathrm{cm}^{-1}\right)\end{array}$ \\
\hline$v_{3} \mathrm{SiO}_{4}^{4^{-}}$ & $980 s, b$ & $970 s, b$ & $977 s, b$ & $959 \mathrm{~s}$ \\
\hline$v_{4} \mathrm{SiO}_{4}^{4^{-}}$ & $536 w$, sh & - & - & - \\
\hline$v_{2} \mathrm{SiO}_{4}^{4^{-}}$ & $467 s$ & - & $453 w$ & $446 w$ \\
\hline \multirow{2}{*}{$v_{3} \mathrm{SiO}_{4}^{2-}$} & $1105 w$, sh & 1100 & $1134 v w, s h$ & $1113 v w$, sh \\
\hline & $1155 w$, sh & - & - & - \\
\hline$v_{4} \mathrm{SiO}_{4}{ }^{2-}$ & $667 w$ & 610 & - & - \\
\hline \multirow{2}{*}{$v_{1}+v_{3} H_{2} \mathrm{O}$} & 3325 & - & - & - \\
\hline & $3450 \mathrm{~s}, \mathrm{~b}$ & $3415 s, b$ & $3436 s, b$ & $3414 m, b$ \\
\hline$v_{2} \mathrm{H}_{2} \mathrm{O}$ & $1630 w$ & $1638 \mathrm{~m}$ & $1656 \mathrm{~m}$ & $1640 w$ \\
\hline $\mathrm{VOH}^{-}$ & $3645 s r, s h$ & $3640 \mathrm{sr}$ & 3644 sr, sh & $3636 s r, s h$ \\
\hline$v_{3} \mathrm{CO}_{3}^{2-}$ & $14251497 \mathrm{~s}, \mathrm{~b}$ & $1421 s, b$ & $1462 s, b$ & $1414 \mathrm{~s}$ \\
\hline$v_{2} \mathrm{CO}_{3}{ }^{2-}$ & $876 \mathrm{~m}, \mathrm{sr}$ & $874 m, s r$ & $875 \mathrm{~m}, \mathrm{sr}$ & $872 s, s r$ \\
\hline$v_{4} \mathrm{CO}_{3}^{2-}$ & $732 w$ & $713 w$ & $718 w$ & $710 w$ \\
\hline
\end{tabular}

b Broad, s strong, sh shoulder, sr sharp, m medium, vw very weak, $w$ weak

$v$ l symmetric stretching, $v_{2}$ symmetric bending, $v_{3}$ asymmetric stretching, $v_{4}$ asymmetric bending

a Mollah et al. [40, 43]

bFarcas and Touze [20]

cPresent study diffuse reflectance

dPresent study ATR 


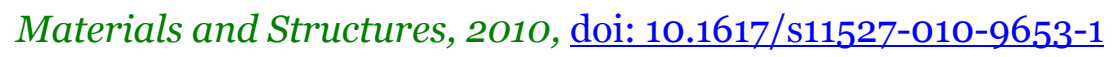

Table 2: FT-IR characterization before and after accelerated weathering [12, 20, 28, 5O].

\begin{tabular}{|c|c|c|c|c|}
\hline Band assignments & $\begin{array}{l}\text { Calcium } \\
\text { carbonate } \mathrm{CaCO}_{3} \\
\left(\mathrm{~cm}^{-1}\right)\end{array}$ & $\begin{array}{l}\text { Non- } \\
\text { weathered }^{b} \\
\text { specimen } \\
\left(\mathrm{cm}^{-1}\right)\end{array}$ & $\begin{array}{l}\text { Carbonated }{ }^{c} \\
\text { specimen }\left(\mathrm{cm}^{-1}\right)\end{array}$ & $\begin{array}{l}\text { Carbonated and } \\
\text { leached specimen } \\
\left(\mathrm{cm}^{-1}\right)\end{array}$ \\
\hline$v_{3} \mathrm{SiO}_{4}^{4^{-}}$ & $970 s, b$ & $959 \mathrm{~s}$ & $970 \mathrm{~s}$ & $970 \mathrm{~s}$ \\
\hline$v_{2} \mathrm{SiO}_{4}^{4^{-}}$ & - & $446 w$ & - & - \\
\hline$v_{3} \mathrm{SiO}_{4}{ }^{2-}$ & 1100 & $1113 v w, s h$ & - & - \\
\hline$v \mathrm{OH}^{-}$ & $3640 \mathrm{sr}$ & $3636 \mathrm{sh}$ & - & - \\
\hline$v_{3} \mathrm{CO}_{3}{ }^{2-}$ calcite & $1421 s, b$ & $1414 \mathrm{~s}$ & $1414 \mathrm{~s}$ & $1414 \mathrm{~s}$ \\
\hline$v_{3} \mathrm{CO}_{3}{ }^{2-}$ aragonite & $1400-1500 \mathrm{~s}, \mathrm{~b}$ & & $1414-1440 s, b$ & $1414-1440 \mathrm{~s}, \mathrm{~b}$ \\
\hline$v_{1} \mathrm{CO}_{3}^{2-}$ vaterite & $1080 w$ & - & & $v_{1} \mathrm{CO}_{3}{ }^{2-}$ aragonite \\
\hline 1083 & - & $1080 \mathrm{w}, \mathrm{sh}$ & $1080 \mathrm{w}, \mathrm{sh}$ & $v_{2} \mathrm{CO}_{3}{ }^{2-}$ calcite \\
\hline $874 m, s r$ & $875 s, s r$ & $876 s$, sh & $876 s$, sh & \\
\hline$v_{2} \mathrm{CO}_{3}{ }^{2-}$ vaterite & $860 \mathrm{~s}, \mathrm{sr}$ & - & $?$ & $?$ \\
\hline $850 \mathrm{~m}, \mathrm{sr}$ & - & $?$ & $?$ & $v_{2} \mathrm{CO}_{3}{ }^{2-}$ aragonite \\
\hline $856 \mathrm{~m}$ & - & $858 s, s h$ & $858 s$, sh & $v_{4} \mathrm{CO}_{3}{ }^{2-}$ calcite \\
\hline $713 w$ & $710 w$ & $714 \mathrm{~m}$ & $714 m$ & $v_{4} \mathrm{CO}_{3}{ }^{2-}$ vaterite \\
\hline $740 w$ & - & $742 w$, sh & - & $710 \mathrm{~m}$ \\
\hline
\end{tabular}

$b$ broad, s strong, sh shoulder, sr sharp, m medium, vw very weak, $w$ weak

$v_{l}$ symmetric stretching, $v_{2}$ symmetric bending, $v_{3}$ asymmetric stretching, $v_{4}$ asymmetric bending, ? certainly covered by another band

a'Simspon [50], Ghosh [28], Farcas and Touzé [20], and Devarajan et al. [12]

bPresent study-non-weathered specimen

cPresent study-carbonated specimen

dPresent study-carbonated and leached specimen 